\title{
GEOECONOMICS OF THE COASTAL REGIONS: THE DEVELOPMENT OF EDUCATIONAL PROGRAMS OF PREPARATION OF MASTERS ${ }^{1}$ \\ ГЕОЕКОНОМІКА ПРИМОРСЬКИХ РЕГІОНІВ: НАПРЯМИ РОЗВИТКУ ОСВІТНЬОї ПРОГРАМИ ПІДГОТОВКИ МАГІСТРІВ
}

UDC 334.021:658:69.009

https://doi.org/10.32843/infrastruct45-11

\section{Wen Mingming}

Ph.D., Associate Professor

School of Management, Guangdong

Ocean University, China

Velychko Volodymyr

Ph.D., Assistant, Department

of Entrepreneurship and Business Administration

O. M. Beketov National University

of Urban Economy in Kharkiv

\section{Grytskov Evgen}

Ph.D., Associate Professor,

Department of Entrepreneurship

and Business Administration

O. M. Beketov National University

of Urban Economy in Kharkiv
It is determined that at the present stage, there is a necessity to form a system of geoeconomics of coastal regions on the basis of ensuring the development of the educational master's program in the directions. The purpose of the study is to determine directions of development and implementation of educational master program in geoeconomics of the coastal regions. To achieve the purpose, the following tasks are solved: description of the educational master program in geoeconomics of the coastal regions; the practice of implementation of educational master program in geoeconomics of coastal regions. It has been determined that the geoeconomics of coastal regions is a system of economic relations of stakeholders at the level of coastal regions, which are formed on the basis of economic indicators, methods and models using geographic information systems and technologies, allowing to monitor changes in the economic system permanently, to predict and make informed management decisions, taking into account the spatial characteristics of coastal regions.

Key words: geoeconomics of the coastal regions, educational master's program, directions for the formation and implementation of the master's program.

Определено, что на современном этапе возникает необходимость формирования системы геоэкономики приморских регионов на основе обеспечения развития образовательной программы подготовки магистров представленного направления. Целью исследования является определение направлений разработки и реализации образовательной магистерской программы по геоэкономики приморских регионов. Для достижения чели решаются задачи: характеристика образовательной магистерской программы по геоэкономики приморских регионов; практика реализации образовательной магистерской программы по геоэкономики приморских регионов. Определено, что геоэкономика приморских регионов представляет собой систему экономических отношений стейкхолдеров на уровне приморских регионов, которые фрормируются на основе экономических показателей, методов и моделей с использованием геоинорормационных систем и технологий, что позволяет перманентно отслеживать изменения в экономической системе, прогнозировать и принимать обоснованные управленческие решения, учитывая пространственные характеристики приморских регионов.

Ключевые слова: геоэкономика приморских регионов, образовательная магистерская программа, направления формирования и реализации магистерской программы.

Визначено, що на сучасному етапі виникає необхідність фрормування системи геоекономіки приморських регіонів на основі забезпечення розвитку освітньої програми підготовки магістрів із представленого напряму. Метою дослідження є визначення напрямів розробки та реалізації освітньої магістерської програми з геоекономіки приморських регіонів. Для досягнення мети вирішуються завдання: характеристика освітньої магістерської програми з геоекономіки приморських регіонів; практика реалізації освітньої магістерської програми з геоекономіки приморських регіонів. Визначено, що геоекономіка приморських регіонів являє собою систему економічних відносин стейкхолдерів на рівні приморських регіонів, що формуються на основі економічних показників, методів і моделей з використанням геоінфьормаційних систем і технологій, що дозволяє перманентно відстежувати зміни в економічній системі, прогнозувати і приймати обгрунтовані управлінські рішення, з огляду на просторові характеристики приморських регіонів. Застосування геоінформаційного інструментарію на рівні приморських регіонів здійснюється відповідно запропонованих етапів: орормування інфрормаційно-аналітичного забезпечення щодо розвитку приморських регіонів створення просторового забезпечення щодо розвитку приморських регіонів; застосування геоінформаційних систем для характеристики економічних показників розвитку приморських регіонів; розробка геоінформаційних карт економічних показників розвитку приморських регіонів; здійснення моніторингу змін економічних показників розвитку приморських регіонів; обгрунтування отриманих результатів. Визначені напрями фрормування та реалізації освітньої магістерської програми з геоекономіки приморських регіонів. У результаті дослідження визначені напрями та особливості формування та реалізації магістерської програми з геоекономіки приморських регіонів, яка дозволяє підготовити квалісікованих спеціалістів, що забезпечують розвиток приморських регіонів, ссрормувати теоретико-методичну платорорму. Ця програма поєднує економічні та геопросторові напрями й характеристики приморських регіонів, що надає можливості фрормування та реалізаціі обгрунтованих управлінських рішень щодо їх фрункціонування.

Ключові слова: геоекономіка приморських регіонів, освітня магістерська програма, напрями фрормування та реалізації магістерської програми.

Problem Statement. The formation of a modern policy of development of the regions is an important task that affects the functioning of the state. Development and implementation of the directions of development of the regions demands the use of modern tools, including geoeconomics, which is an innovative system on the basis of which the development of managerial decisions, analysis and monitoring of economic indicators

\footnotetext{
${ }^{1}$ This article (monograph) is supported by the project of Enhancing School With Innovation of Guangdong Ocean University's (230420023) and by the program for scientific research start-up funds of Guangdong Ocean University
}

using geographic information systems are provided. This approach allows to visualize a complex regional system in space to provide the mapping between them. In regional development the maritime regions, which have certain characteristics and have a significant impact on the development of the state, are of special importance. At the present stage there is a necessity of formation of system of geoeconomics of the coastal regions on the basis of ensuring the development of the educational master's programme in the directions. Thus, the research topic is relevant and important for the development of the coastal regions. 
Literature Review. Scientists are engaged in solving the problems of the formation and implementation of the regional economy, such as S. Varnalii [1], A. Holikov [2], B. Danylyshyn [3], S. Dorohuntsov [4], V. Lyshylenko [5], T. Serikova [ 6]. V. Semenov [7], M. Khvesyk [8] and others.

The development and application of geoinformation systems were solved in [9].

However, the issues of defining and applying the geoeconomics of the coastal regions on the basis of theoretical and practical aspects through the introduction of a modern master's program remain unresolved.

Materials and methods. The study uses general and special methods, where a particular attention is focused on analytical and expert methods, generalization and systematization, economic and mathematical modeling and geoinformation analysis.

Research Objective. The purpose of the study is to determine the directions of development and implementation of educational master's program in geoeconomics of the coastal regions.

To achieve the goal, the following tasks are solved:

- characteristics of the educational master's program in geoeconomics of the coastal regions;

- practice of realization of the educational master's program on geoeconomics of coastal regions.

Key Results. Summarizing the existing theoretical and methodological issues, there is proposed the definition of geoeconomics of the coastal regions, which is a system of economic relations of stakeholders at the level of the coastal regions, which are formed on the basis of economic indicators, methods and models using geographic information systems and technologies, allowing to permanently monitor changes in the economic system, to predict and make informed management decisions, taking into account the spatial characteristics of coastal regions.

The application of GIS tools at the level of the coastal regions is carried out according to the proposed stages:

1. The formation of information-analytical providing of development of coastal regions.

2. The creation of spatial development of coastal regions.

3. The use of GIS to characterize the economic indicators of the development of coastal regions.

4. The development of GIS maps of the indicators of economic development of coastal regions.

5 . The monitoring of changes in economic indicators of development of the coastal regions.

6 . Justification of the results.

The stages of implementation of geographic information systems based on the generated GEODATA, mapping, and spatial software, are proposed under. Along with this, you can apply the results of the evaluation of territorial development, land use regions, which are shown in Figures 1-2.

In the coastal regions of Ukraine, as in other regions, there is a low rate of their development, which requires radical action to increase the spatial, urban, environmental and investment factors.

Geoinformation support of the coastal regions of China is presented in Figures 3-8.

It should be noted that for training of specialists of geoeconomics of the coastal regions, the national geospatial data infrastructure is applied, which is designed for the collection, processing, storage,

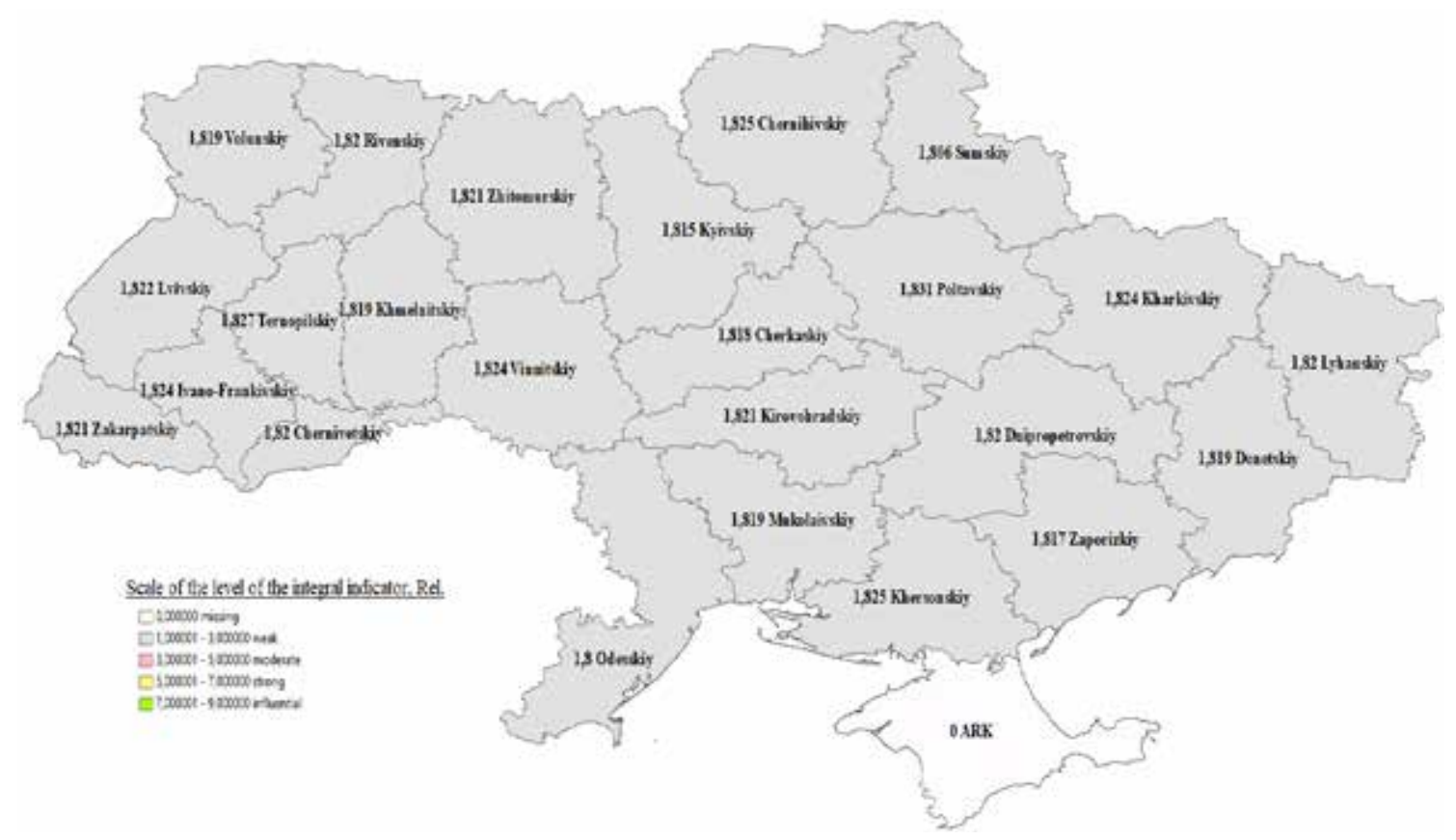

Figure 1. Geographic information map of integrated indicators of territorial development of land use of regions, rel. 


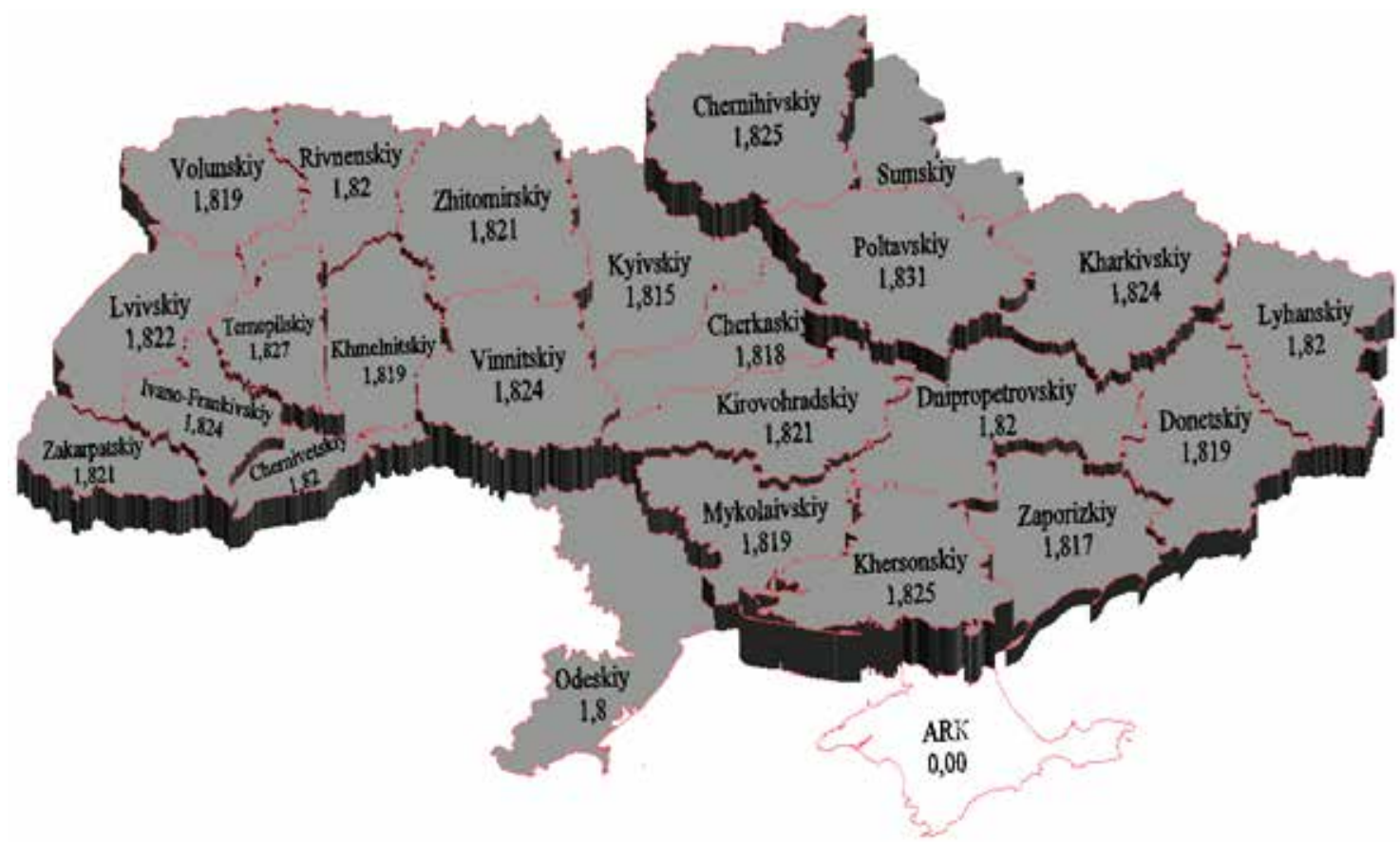

Figure 2. Geoinformation three-dimensional model of monitoring the state of territorial development of land use of regions, rel.

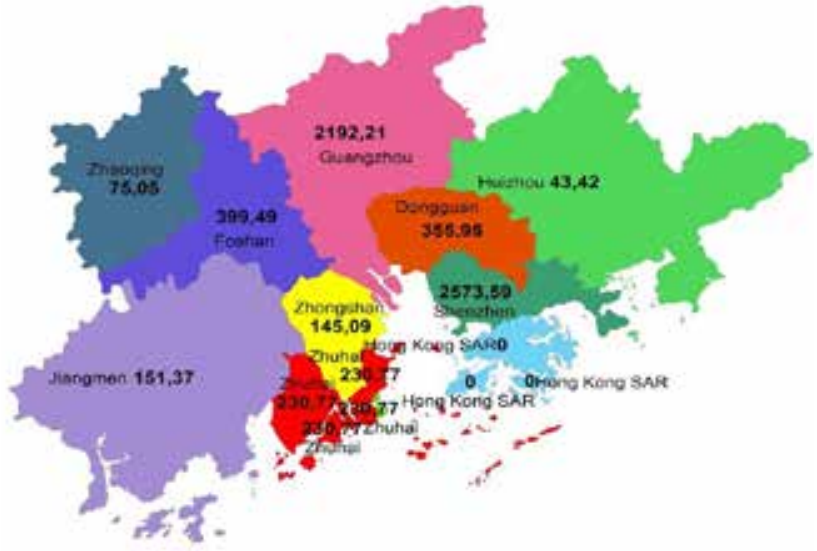

Figure 3. Geoinformation map according to the indicator Container Throughput (10000 TEUs) of coastal regions of China

dissemination and effective use of information defined in a certain space-time coordinates of objects and phenomena that are directly or indirectly related to the location of such objects on the Ground [9].

Basic geopositioning data is information on: the reference system of coordinates and altitudes; the state border; administrative and territorial units, including their boundaries; territorial communities, including the boundaries of their territories; the drainage facilities and hydraulic structures; settlements, including the road network; buildings and structures; roads; railways; engineering communications; airports, sea and river ports; land cover and soils; land plots; register of streets and addresses of objects; geographical names; digital elevation model; orthophoto [9].

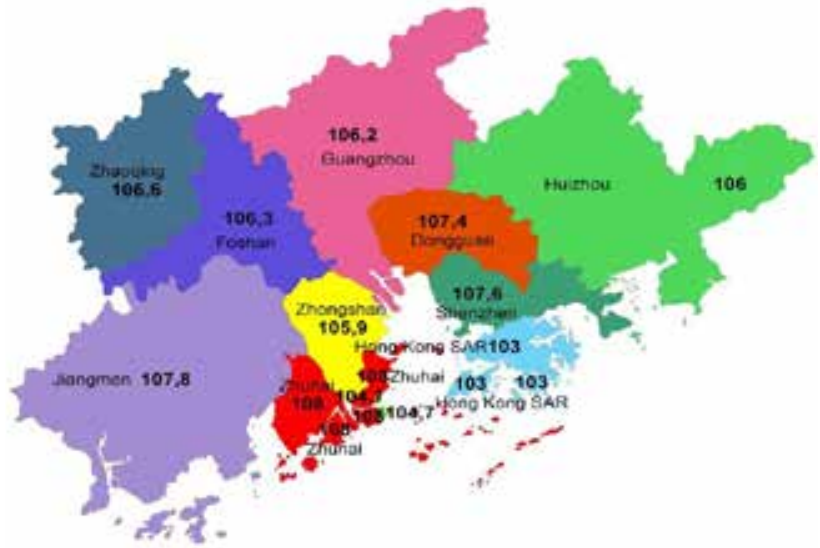

Figure 4. Geoinformation map according to the Index (prece-ding year $=100$ ) of the coastal regions of China

In the theme of geospatial data, all types of geospatial data, which are generated based on the basic geospatial data or as separate data sets, are included.

Functioning of the national geospatial data infrastructure approved by the Cabinet of Ministers of Ukraine determines:

1) composition of base geospatial data and geospatial data specified in the Annex to the Law;

2) the bodies of Executive power, bodies of local self-government and other holders responsible for creating and updating geospatial data and metadata;

3) the organization of production, updating, processing, storage, representation, visualization, use of geospatial data and metadata, other activities with them [9]. 


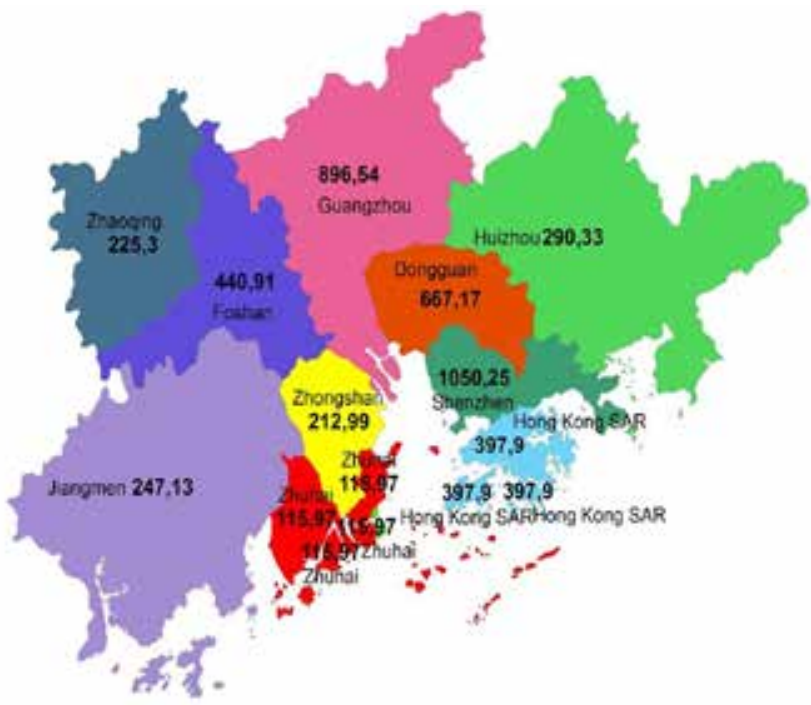

Figure 5. Geographic information map according to the Labor Force (10000 persons) of the coastal regions of China

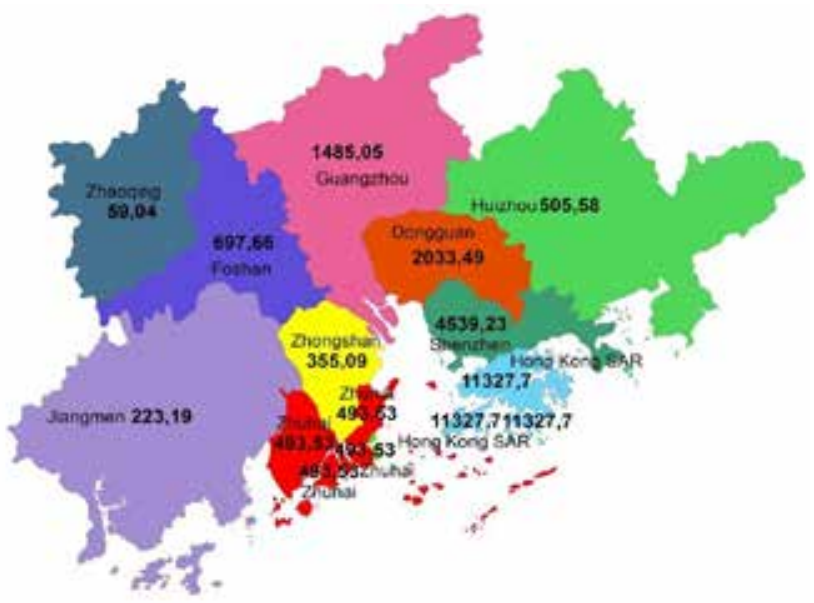

Figure 7. Geoinformation map according to the indicator of Total Exports (100 million USD) of the coastal regions of China

The underlying geospatial data should not contain information constituting a state secret and other information, access to which is restricted in accordance with law (information restricted).

Metadata provide background information on the composition, structure, quality, territorial coverage, features, terms of use of geospatial data and services and may contain other supplementary information.

Responsibility for the accuracy, completeness, precision and relevance of geospatial data and metadata carries the holder of the treatment [9].

It is determined that users' access to geospatial data and metadata is provided through geoportals of data holders and the official website of the national geospatial data infrastructure. The central executive body that implements the state policy in the field

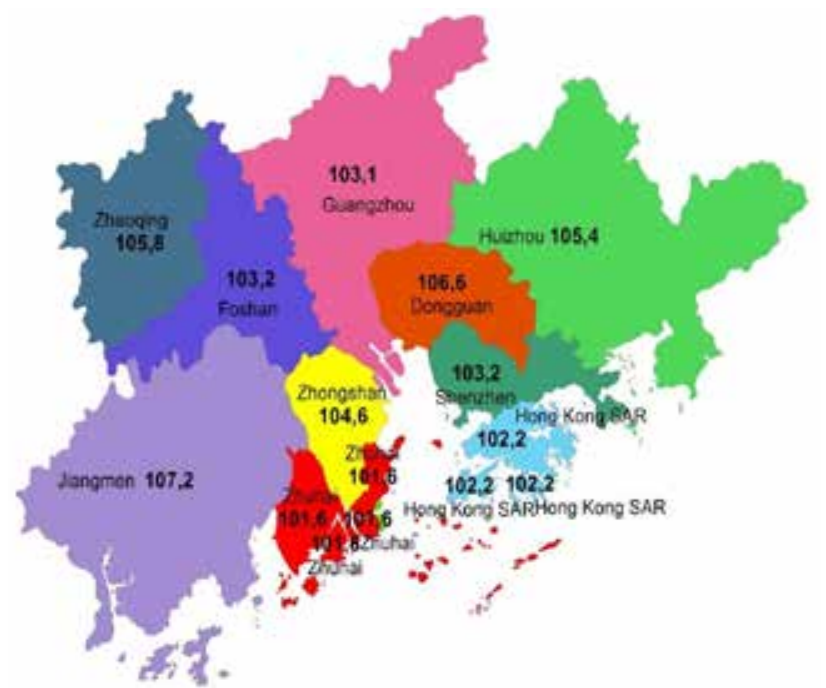

Figure 6. Geographic information map according to the Per Capital GDP (Index-preceding year $=100$ ) of the coastal regions of China

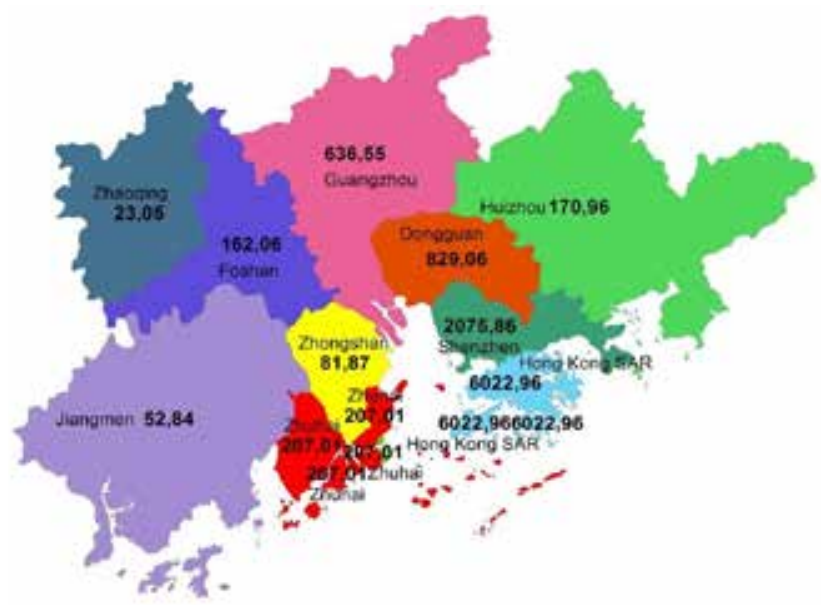

Figure 8. Geographic information map according to Total Imports (100 million USD) of the coastal regions of China

of national geospatial data infrastructure provides users with access to geospatial data and metadata of the national geospatial data infrastructure through the national geoportal. Access to geospatial data and metadata of executive authorities and local governments is provided free of charge to all users, unless otherwise provided by law. Executive and local governments publish all geospatial data and metadata on the Internet, except for data related to restricted information. Executive authorities and local governments are obliged, and individuals and legal entities have the right to publish metadata in their possession through the services of the national geoportal. Executive and local governments are required to publish geospatial data and metadata on their official websites and / or geoportals on the Internet 
and to display them through access services on the national geoportal. In case the Executive authority or the local authority does not have its own geoportal, he or she has the right to apply to any other holder of the geoportal in accordance with its sectoral or geographical coverage for the promulgation of such geospatial data, metadata, and, in the case of agreement, to perform other actions with them. Reduction of volume and/or reduction in the quality of existing organs of executive power and bodies of local self-government geospatial data and metadata for publication on the Internet is not allowed. If the geospatial information authority of Executive power or body of local self-government existing in the form that gives you the opportunity to reflect them in vector form, the above-mentioned authorities are ensured by the publication of such data on the Internet in vector form. If the producer of data to be transferred to an executive body or a local self-government body performs actions with them in vector form, such geospatial data must be transferred to the relevant body, including in vector form. Data holders, including executive authorities and local governments, have the right to create and develop access to each other's data without the use of national geoportal services. Data holders have the right to restrict access to geospatial data and metadata in accordance with the Law of Ukraine "On Access to Public Information". Users' access to the national portal of geospatial data from the territory of the aggressor state is subject to blocking [9].

As part of the national geospatial data infrastructure, a national geo-portal and other geoportal for sectoral or territorial scope are established and operated. The creation, operation and development of the national geoportal provides a Central Executive authority that implements the state policy in the sphere of national geospatial data infrastructure. Holder of the national geoportal is the Central Executive authority that implements the state policy in the sphere of national geospatial data infrastructure. Intellectual property rights at the national geoportal belong to the state in person of Central body of Executive power that implements the state policy in the sphere of national geospatial data infrastructure. At the national geoportal, basic geospatial data and metadata, and geospatial data and metadata for geographic information systems are displayed, which in accordance with the legislation are ensured by the bodies of state power and bodies of local self-government, it is possible to display other geospatial data and metadata. In the national geoportal bodies of Executive power and bodies of local self-government the following network services are established and operated: 1) search services, which provide the identification of geospatial data and metadata; 2) view services for geospatial data and metadata; 3) access services geospatial data and metadata, including in the forms of downloading data and application programming interfaces; 4) transformation services geospatial data with the goal of achieving interoperability; 5) other services for the implementation of geopositioning data and metadata, including services for the provision of administrative services. Network geoportal services are created and evolve based on the suggestions of users, providing ease of operation in the Internet on the basis of common web browsers and editors without the need for a specially created for this technology and software around the clock without restrictions. At the request of geospatial data holders and with the consent of the central executive body implementing the state policy in the field of national geospatial data infrastructure, geospatial data and metadata of such geospatial data holders are displayed on the national geoportal using access services. The list of grounds for refusal to display geospatial data and metadata on the national geoportal is determined by the Cabinet of Ministers of Ukraine in the Procedure for functioning of the national geospatial data infrastructure [9].

Conclusions. As a result of the research, the directions and features of formation and realization of the master's program on geoeconomics of the coastal regions, which allows to prepare the qualified experts providing development of coastal regions, to form the theoretical and methodical platform, are defined. This program combines economic and geospatial directions and characteristics of the coastal regions, which provides opportunities for the formation and implementation of sound management decisions for their operation.

\section{REFERENCES:}

1. Varnalii Z. S. (2005) Rehiony Ukrainy: problemy ta priorytety sotsialno-ekonomichnoho rozvytku [Regions of Ukraine: problems and priorities of socio-economic development]: monohrafiia. Kyiv (in Ukrainian)

2. Holikov A. P., Deyneka O. H., Pozdniakova L. O., Chernomaz P. O. (2009) Rehionalna ekonomika ta pryrodokorystuvannia [Regional economy and nature management]. Kyiv: Tsentr navch. literatury (in Ukrainian)

3. Danylyshyn B. M., Dorohuntsov S. I., Mishchenko V. S., Koval Ya. V., Novotorov O. S., Palamarchuk O. M. (1999) Pryrodno-resursnyy potentsial staloho rozvytku Ukrainy [Natural resource potential of sustainable development of Ukraine]. Kyiv, RVPS Ukrainy (in Ukrainian)

4. Dorohuntsov S. I., Oliynyk Ya. B., Stepanenko A. V. (2001) Teoriia rozmishchennia produktyvnykh syl i rehionalnoi ekonomiky [Theory of location of productive forces and regional economy]. Kyiv, «Stafed-2» (in Ukrainian)

5. Lyshylenko V. I. (2013) Rehionalna ekonomika [Regional economy]. Kyiv: Tsentr uchbovoï literatury (in Ukrainian)

6. Sierikova T. M., Hikovata N. K., Shumska H. M. (2011) Rehionalna ekonomika u skhemakh i tablytsiakh [Regional economy in schemes and tables]. Kharkiv: Vyd KhNEU (in Ukrainian) 
7. Semenov V. F. (2013) Rehionalna ekonomika [Regional economy]. Kyiv: TsUL (in Ukrainian)

8. Khvesyk M. A., Horbach L. M., Pastushenko P. P. (2005) Rozmishchennia produktyvnykh syl ta rehionalna ekonomika [Location of productive forces and regional economy]. Kyiv: (in Ukrainian)

9. Pro natsionalnu infrastrukturu heoprostorovykh danykh [About the national infrastructure of geospatial data]. Zakon Ukrainy. Dokument 554-IX. URL: https://zakon.rada.gov.ua/laws/show/554-20.

\section{БІБЛІОГРАФІЧНИЙ СПИСОК:}

1. Регіони України: проблеми та пріоритети соціально-економічного розвитку: монографрія / за ред. 3. С. Варналія. К.: 2005. 498 с.

2. Голіков А. П., Дейнека О. Г., Позднякова Л. О., Черномаз П. О. Регіональна економіка та природокористування: навч. посіб. К.: Центр навч. літератури, 2009. 352 с.
3. Данилишин Б. М., Дорогунцов С. І., Міщенко В. С., Коваль Я. В., Новоторов О. С., Паламарчук О. М. Природно-ресурсний потенціал сталого розвитку України. Київ, РВПС України. 1999. 716 с.

4. Дорогунцов С. І., Олійник Я. Б., Степаненко А. В. Теорія розміщення продуктивних сил і регіональної економіки: навч. посіб. К.: «Стафред-2», 2001. 144 с.

5. Лишиленко В. І. Регіональна економіка: підручник. К.: Центр учбової літератури, 2013. 225 с.

6. Серікова Т. М., Гіковата Н. К., Шумська Г. М. Регіональна економіка у схемах і таблицях: навчально-практичний посібник Х.: Вид ХНЕУ, 2011. 176 с.

7. Семенов В. Ф. Регіональна економіка: навч. посібник. К.: ЦУЛ, 2013. 566 с.

8. Хвесик М. А., Горбач Л. М., Пастушенко П. П. Розміщення продуктивних сил та регіональна економіка: навч. посібн. К.: Кондор, 2005. 344 с.

9. Про національну інфрраструктуру геопросторових даних. Закон України. Документ 554-IX. URL: https://zakon.rada.gov.ua/laws/show/554-20. 